\title{
Do lado de fora do jardim encantado: comunicação e desencantamento do mundo
}

\section{Malena Segura Contrera}

\section{Resumo}

0 presente artigo se propõe a resgatar o sentido comum presente nos termos comunicação e comunhão, analisando as origens desses dois processos em busca de sua raiz comum e da discussão acerca das condições sócio-culturais que promoveram, em determinado momento de nossa história, uma dissociação entre esses dois processos, dissociação essa a partir da qual o sentido de comunicação se transformou radicalmente, favorecendo a imposição de uma visão meramente funcional e utilitarista sobre comunicação. Palavras-chave

Desencantamento do mundo. Mídia. Incomunicação.
Malena Segura Contrera I malenacontrera@uol.com.br Universidade Paulista. Doutora em Comunicação e Semiótica pela PUC- São Paulo - UNIP. Atualmente é professora titular do curso de mestrado em Comunicação da Universidade Paulista. É autora dos livros 0 mito na mídia (1996), Mídia e Pânico (2002), Jornalismo e Realidade (2004), e de diversos outros artigos e capítulos de livros em coletâneas e revistas científicas. Coordena atualmente intercâmbio de pesquisa com as Universidade chilenas Austral de Valdívia e Playa Ancha de Valparaiso.

\section{Um cenário de desencantamento}

Os jornais apresentam diariamente os

desdobramentos contemporâneos das

transformações sócio-culturais ocorridas

nos últimos séculos, os resultados do

capitalismo tardio ${ }^{1}$ que estendeu seus braços

à maior parte do mundo, com a consequente

globalização econômica e suas rachaduras, suas incongruências, sua insustentabilidade ${ }^{2}$. No entanto, muito pouco se fala, nos jornais ou fora deles, a respeito da visão de mundo que subjaz e sustenta esse paradigma sócio-econômico, vigente tanto no território da ciência e da tecnologia, quanto no território da ética e da religião que as balizam. Pouca coisa também se tem falado a respeito das profundas transformações semióticas ocorridas nesse cenário, de como as sociedades contemporâneas tecnológicas vêm operando uma profunda crise nos processos de significação, que põem do avesso os sentidos partilhados e as comunicações que a partir deles se constroem.

Talvez a mais relevante contribuição a essa reflexão que se tornou objeto de atenção dos estudos da área de comunicação tenha sido 
a importante contribuição de Max Weber

(2004) sobre a ética protestante e 0 espírito do capitalismo. As reflexões estimuladas por essa contribuição, no entanto, seguiram em sua grande maioria pelo viés da crítica econômica e de seus desdobramentos sociais. No geral, há um grande silêncio acerca da concepção de mundo específica e do paradigma científico que viabilizaram essa situação que Weber chamou, no cenário religioso da ética protestante, de "a conclusão do grande processo históricoreligioso de desencantamento do mundo"3, situação essa que ainda hoje sustenta essa concepção de mundo.

A perspectiva funcional/utilitarista, que atribui importância quase exclusiva às aplicações práticas na área de Comunicação (o "como fazer" dos manuais vendidos aos milhões), e o sucesso econômico que se espera obter com essas práticas, e a herança do pensamento bélico que encara a comunicação como uma mera troca de informações, enfoque muito adotado até hoje no Jornalismo, são dois sintomas claros do que entendemos que seja 0 atual estado de desencantamento da comunicação contemporânea.
Utilitarismo e visão maquínica são heranças históricas que nos levam a esse atual cenário de desencantamento que passa necessariamente pela relação do homem com seu meio ambiente e com outros homens, logo, por suas relações comunicativas.

Para compreender melhor essa visão de mundo à qual nos referimos e que é 0 entorno noosférico da maior parte do pensamento sobre comunicação, foi preciso buscar essa concepção de mundo nas análises trazidas pela história da ciência, em vista finalmente de algumas chaves interpretativas relevantes acerca de como se tem pensado o mundo nos últimos três séculos, e de como esse pensamento incide diretamente sobre a comunicação contemporânea.

\section{0 mundo morto da ciência moderna - a dissociação entre 0 sujeito e 0 objeto}

Chama a atenção o fato de quase sempre passar despercebida a semelhança de sentidos entre os termos comunhão e comunicação. Comunhão se tornou assunto de religião, enquanto a comunicação foi apropriada, na grande maioria das vezes, pelo pensamento técnico-instrumental ou então pela máquina de guerra.

Sobre o fenômeno do capitalismo tardio, referimo-nos à proposta de F. Jameson (1997), em Pós-modernismo - A lógica cultural do capitalismo tardio.

Autores que, por exemplo, tratam dessa questão da insustentabilidade do atual paradigma capitalista, e que expandem essa questão para além da esfera meramente econômica, são William I. Thompson, Fritjot Capra, James Lovelock, Lynn Margulis, Hazel Henderson, propondo uma reflexão sobre novos rumos da ação ecológica que considerem uma ação expandida a partir das questões centrais sobre meio-ambiente não apenas natural, mas também sobre meio-ambiente econômico e social.

Nas palavras de Max Weber: "Aquele grande processo histórico-religioso do desencantamento do mundo que teve início com as profecias do judaísmo antigo e, em conjunto com o pensamento científico helênico, repudiava como superstição e sacrilégio todos os meios mágicos de busca da salvação, encontrou aqui sua conclusão" (WEBER, 2004, p. 96). 
A profunda imbricação presente nas raízes dos dois processos é, no entanto, ignorada. 0 discurso religioso não a recupera ao falar da comunhão porque se trata quase sempre de um discurso de vocação cristã, nem um pouco interessado em regressar às raízes pagãs das sociedades primevas (onde é preciso ir buscar 0 entendimento do termo comunhão), apropriando-se desse fenômeno para restringilo à comunhão com Cristo ou com a igreja que, em questão, propõe representá-lo. Por sua vez, o discurso sobre comunicação ocupase quase exclusivamente de fazê-la servir como instrumento funcional na produção das ininterruptas trocas de informação, fazendo essa produção seguir melhor e mais rentosamente, ou, na melhor das hipóteses, abordando seus princípios sociopolíticos, sem, no entanto, aventurar-se pela busca das raízes da comunicação (excetuando-se honrosas exceções). Temos como resultado que a profunda afinidade original entre esses dois conceitos seja objeto de pouco interesse em nossa área.

Há um grande equívoco em se considerar que comunhão pressuponha entendimento ou concordância. A comunhão, tal como a concebemos, refere-se de fato a um estado de pertencência à espécie humana, algo que Morin (1995) chamou de "destino planetário", que obviamente abriga divergências e confrontos. No entanto, esses confrontos ocorrem dentro de um sentimento de que "aquilo me diz respeito de alguma maneira". Por isso gastamos nosso tempo de vida em discussões na tentativa de criar acordos sociais quando talvez fosse mais rápido e mais fácil "eliminar" o adversário simplesmente. A experiência, porém, ensinou que eliminado 0 adversário aqui, brotam ali outros tantos novos adversários, até que se reconheça em cada um de nós, internamente, o próprio adversário.

A comunicação está muito próxima dessa forma de comunhão. Por não ser mera sociabilidade no sentido do estabelecimento de acordos sociais simples, mas a busca de um sentimento de destino humano comum, que por vezes transcende as circunstâncias pragmáticas, é que consideramos que 0 termo comunhão propõe uma diferença essencial. Essa comunhão só é possível por meio da experiência comum não-ordinária (e com um grande movimento de padrões inconscientes), por meio da criação de uma base comum que consideramos chamar de vínculo4.

Por trás da experiência comunicativa, tal qual por trás da experiência religiosa de comunhão, está então 0 anseio a uma certa fusão psíquica, da qual não se sai exatamente 
igual se entrou. Alguns dizem que essa

"diferença" que esse encontro faz é a informação

que dele tiramos, mas creio que informação não

seja um termo muito feliz para designar essa

espécie de transformação. Ousaria sugerir 0

termo alquimia, que talvez represente melhor

esse desejo primitivo que em nós permanece

pela integridade psíquica que a irrupção da

consciência destruiu e pela fusão cósmica

advinda do estado pré-consciente ${ }^{5}$.

No entanto é preciso entender que se esses

dois termos têm ainda hoje tanto em comum

é porque, na realidade, até fins do século XVI

eram praticamente a mesma coisa, já que a visão

de mundo até então vigente não dissociava de

maneira tão radical o homem do ambiente em

que ele vivia (e de seus outros), e foi somente

a visão de mundo cartesiana/newtoniana, no

século XVII, que propôs oficialmente essa

dissociação, rapidamente acatada pelo nascente

espírito do capitalismo.

Segundo Morris Berman, o cenário científico europeu até o final do século XVI seguia os pressupostos herméticos, assim apresentados:

La "sabiduría hermética", como ha sido denominada, estaba en efecto dedicada a la noción de que el conocimiento verdadero ocurria únicamente vía la unión del sujeto y el objeto, en una identificación psíquico-emocional con imágenes en lugar de la examinación puramente intelectual de los conceptos [...] Es el colapso de este universo mental, que comenzó (si tal cosa puede ser fechada) a fines del siglo XVI, lo que delimita tan radicalmente el mundo medieval del mundo moderno [...] (BERMAN, 2005, p. 73-75).

Essa visão medieval propõe a respeito da relação sujeito/objeto, nos termos da época, uma visão totalmente análoga ao que a física quântica contemporânea apresenta como a impossibilidade de se excluir o comportamento do observador do fenômeno observad $0^{6}$, ou seja, a impossibilidade da dissociação entre, por exemplo, as partes envolvidas em uma situação comunicativa. Isso põe por terra, desde sempre, a divisão entre emissor e receptor, 0 que não foi feito apenas com o surgimento das tecnologias digitais da comunicação, como alguns propõem.

Essa identificação psíquico-emocional da qual fala Berman se aproxima exatamente do conceito de comunhão, que também possui estreita relação com a noção de participação mística, esse sentimento oceânico desde sempre tão presente nas narrativas mitológicas, e ainda hoje presente nos sonhos e nos estados alterados da consciência (0 que inclui os quadros psicopatológicos). Justamente por tratar dos fenômenos da

Esses pontos, bastante trabalhados por toda a Antropologia e pela Psicologia Profunda, são especialmente tratados por Edgar Morin (1988) no livro 0 paradigma perdido - o enigma do homem, e por Erich Neumann, no livro A história da origem da consciência.

Conforme as teorias sobre física quântica apresentam as experiências com partículas e moléculas (ver F. Capra, 2004, em $A$ teia da vida e As conexões ocultas). 
psique é que Carl G. Jung, partindo do conceito proposto inicialmente por H. Lèvi-Bruhl, retoma a noção de participação mística, ressaltando sua relevância:

A camada mais profunda que conseguimos atingir na mente do inconsciente é aquela em que 0 homem 'perde' a sua individualidade particular, mas onde sua mente se alarga mergulhando na mente da humanidade - não a consciência, mas 0 inconsciente, onde somos todos iguais (...) A esse nível coletivo não somos mais entidades separadas, somos um. Podemos compreender isso quando estudamos a psicologia dos povos primitivos. 0 fato que mais salta à vista, na mentalidade primitiva, é essa falta de diferenciação entre os indivíduos, essa união de sujeito e objeto, essa 'participation mystique', como a chama Lèvy-Bruhl (JUNG, 2000, p. 59) $)^{7}$.

Berman defende que essa participação mística, longe de ser uma condição do homem primitivo, como afirma o senso comum, é parte da natureza humana em si mesma, ou, melhor dizendo, parte da condição básica de toda matéria viva, e propõe uma noção ampliada desse fenômeno que, no âmbito dos processos de consciência humanos, poderia ser designado pelo termo consciência participativa .

Essa consciência participativa leva o homem a buscar uma forma de profunda interação afetiva e psíquica com o mundo com o qual interage, estabelecendo uma forma de comunhão com 0 que James Hillman designa, seguindo uma longa tradição de pensamento ${ }^{8}$, de alma do mundo, manifesta nos objetos almados de um mundo vivo:

Então, percebemos que o que a psicologia determinou chamar de "projeção" é simplesmente animação, à medida que esta ou aquela coisa ganha vida, chama nossa atenção, atrai-nos. № entanto, esta súbita iluminação do objeto não depende de sua parte formal e estética que 0 faz "belo", mas sim dos movimentos da anima mundi animando suas imagens e afetando nossa imaginação. A alma do objeto corresponde e une-se à nossa (HILLMAN, 1993, p. 15).

Essa forma de consciência estaria diretamente em oposição a uma consciência não-participativa que propõe uma abordagem exclusivamente

7 Jung insere neste momento um rodapé acerca desse conceito de Lèvy-Bruhl, no qual assinala o ataque que este último sofreu por parte de etnólogos e antropólogos, levando-o posteriormente a recapitular sobre essa questão. No entanto, Jung reafirma esse conceito e diz que ele trata exatamente de um processo de identificação inconsciente, bastante compreensível pela ótica dos fenômenos da psique. Ele afirma que: "Para evitar mal-entendidos devo lembrar que Lèvy-Bruhl infelizmente retirou depois este termo devido a pressões da crítica negativa. Mas seus críticos não têm razão, pois a identidade inconsciente é um fato psicológico bem conhecido" (JUNG, 2000, p. 197).

Segundo J. Hillman: "Essa ideia é afirmada de diferentes formas em Platão, pelos estoicos, em Plotino e nos míticos cristãos e judaicos; manifesta-se esplendidamente na Psicologia Renascentista de Marsilio Ficino, em Swedenborg; é reverenciada na Mariologia, na devoção Sofiânica e no Shekinah. Encontramos noções dela nos românticos alemães e britânicos e nos transcendentalistas americanos; em filósofos do panpsiquismo, de Leibniz até Peirce, Schiller, Whitehead e Hartshorne. A alma do mundo também retorna na posição pluralista de William James por meio de seu interesse em Fechner e sua preocupação com o 'particular, o pessoal e 0 insalubre' - a singularidade dos acontecimentos em vez de totalidades abstratas. A anima mundi reaparece em outras formas: como o 'coletivo', em Jung; como caráter fisiognômico na Gestalt de Koffka e Köhler; na fenomenologia de Merleau-Pounty, de van der Berg; na poética da matéria e do espaço de Bachelard, e até mesmo em Roland Barthes e, claro, ocasionalmente, nos grandes poetas, principalmente deste século, em Yeats, Rilke e Wallace Stevens" (HILLMAN, 1993, p. 27). 
racional do mundo (quando ainda se pensava que isso fosse possível ${ }^{9}$ ), na qual o sujeito, no topo antropocêntrico da cadeia evolutiva, vê o mundo de forma objetal e desprovido de vida, de alma.

No entanto, a consciência participativa é excluída a partir do século XVI (com pequenas ilhas de sobrevivência e resistência) e é substituída pelo paradigma mecanicista de ciência, muito mais conveniente aos interesses econômico-políticos que despontavam. Berman ressalta a afinidade ideológica entre este novo paradigma e a visão econômica que despontava:

Para esos grupos la idea de la materia viviente no constituía tan solo una herejía, sino que también era inconveniente desde el punto de vista económico. Una tierra inanimada rompe el delicado equilibrio ecológico que se mantenía en la tradición alquímica, pero si la naturaleza es algo muerto, entonces no hay restricciones para explotarla en beneficio propio (BERMAN, 2005, p. 124).

É preciso considerar ainda que essa visão hermética medieval abrigava uma visão religiosa panteísta que propiciava uma gama de cultos e seitas mais ou menos autônomos e autogestados, dando uma certa autonomia a pequenos grupos de poder que conviviam de forma não-centralizadora.

Certamente que ao espírito do tempo moderno, expansionista, centralizador e titânico $0^{10}$, que preparava 0 cenário adequado para 0 surgimento e 0 triunfo da industrialização e do capitalismo, essa visão de mundo e essas práticas religiosas não convinham. Como afirma ainda M. Berman: "La ciencia moderna es el esquema mental de un mundo definido por la acumulación de capital, y finalmente, citando a Ernest Gellner, se convirtió en el 'modo de cognición' de la sociedad industrial" (BERMAN, 2005, p. 49).

Esse modo de cognição da sociedade industrial predominou nos últimos séculos, e por isso precisamos nos perguntar acerca de a que valores e interesses, ainda hoje, serve essa visão de mundo mecanicista que nasce no século XVII, e que segue sendo praticada nas esferas políticas da ciência (o que muitas vezes pauta o pensamento científico), mesmo após o desmonte trazido pelo paradigma quântico das últimas décadas. Essa visão mecanicista continua a promover o triunfo da quantidade em detrimento da qualidade, da funcionalidade em detrimento do significado, da eficiência em detrimento da criatividade e da livre experimentação.

As implicações desse cenário no universo da comunicação são evidentes, mas ainda assim vale elencar algumas delas:

As modernas teorias da cognição afirmam que é impossível dissociar os processos afetivos dos construtos racionais. Um neurologista que fala longamente sobre esse ponto é A. Damásio no livro 0 mistério da consciência (2000).

10 Sobre o titanismo na cultura e na comunicação nos remetemos ao texto "Os maiores e os melhores do mundo: o titanismo na comunicação e na cultura”, da presente autora, publicado no livro da 12a. Compós - Mídia.BR. 
a) índices de audiência e valoração suprema dos medidores de impacto no lugar da significância, transformando as estratégias de marketing (o que inclui o marketing pessoal e a política de interesses) no atual ethos da comunicação;

b) a importância atribuída atualmente à funcionalidade tecnológica dos meios de comunicação e a minimização da discussão acerca do impacto semiótico e psicoafetivo desses meios junto à sociedade, $\mathrm{e}$ especialmente, se e como eles cumprem seu papel de mediação (basta ver que os investimentos financeiros em pesquisa são quase sempre direcionados para 0 desenvolvimento e a aplicação de novas tecnologias à comunicação);

c) a imposição da máquina funcional da grande mídia, que garante a padronização e a velocidade de circulação da informaçãomercadoria (seja ela jornalística, pseudoeducativa ou de entretenimento) em detrimento do tempo lento da reflexão, da experimentação e da criação, definindo 0 mercado de trabalho na área.

No entanto, outras implicações menos óbvias chamam também a nossa atenção. 0 fato de que a lógica econômica monetária tenha definido o "dinheiro" como valor supremo, senão como o único valor na maioria dos casos, é a primeira delas.

\section{Quando 0 único valor de algo é seu valor monetário - o show business}

0 primeiro grande passo para a imposição

do valor monetário como 0 grande valor absoluto que constatamos nas sociedades contemporâneas certamente se dá com 0 início da industrialização e com a apropriação do tempo de vida dos trabalhadores. Se até então 0 artesão ou agricultor da sociedade pré-industrial conseguia sustento econômico a partir da venda ou do escambo dos bens que produzia, a nova configuração econômica do século XIX vai sujeitar o homem, como propõe a teoria marxista, à venda do seu tempo de vida:

\begin{abstract}
Se na Idade Média o tempo era ainda um dom divino, a economia do tempo foi acompanhada da secularização. 0 tempo de trabaIho converteu-se hoje no tempo remunerado pelo sistema industrial próprio deste modelo civilizatório. Em consequência, o trabalho não retribuído, informal ou clandestino, não é socialmente reconhecido, posto que o tempo dedicado a ele não se pode medir, dividir, racionalizar. Esta hierarquia de valores e de emprego do tempo reforça a produção material e converte a economia no centro da vida (ROMANO, 2006, p. 3).
\end{abstract}

Essa conversão da economia no centro da vida é exatamente o que estamos aqui observando. Há pelo menos dois séculos as pessoas vendem o seu tempo de vida, e não necessariamente 0 resultado do que produziam nesse tempo. Essa fórmula, que começa há poucas décadas a ser questionada e repensada, é a que ainda hoje prevalece, especialmente entre o que se chama 
de classe assalariada - trabalha-se "x" horas por dia e recebe-se por essa grade horária, pelos turnos de trabalho $0^{11}$.

Converte-se assim facilmente 0 tempo em dinheiro. "Time is money" é um dos batidos jargões do mundo capitalista e de maneira simplista, mas muito precisa, define o tom que assumiu a vida das pessoas nos grandes centros de produção.

No entanto, a questão se complexifica se pensamos que, em realidade, tempo é vida, que não há nada mais próximo do que podemos considerar como energia vital do que o tempo de vida de cada um, já que é o único bem inalienável, a única coisa que, por definição, não se pode restituir. No dia de nossa morte não podemos apelar solicitando a restituição do tempo perdido em vivências que não valeram a pena. Logo, vender o tempo é efetivamente vender a energia vital, o que equivaleria a dizer "vender a alma".

Essa imagem, apesar de muito recorrente na literatura e no cinema, ainda resulta profundamente desconfortável para todos nós que nascemos e vivemos toda a vida nessa lógica econômica sem, na maior parte das vezes, termos opções conscientes ou rotas de fuga. Exatamente por isso, porque a imagem é indigesta, criamos estratégias simbólicas para inverter a situação de maneira que aquilo que consigamos em troca, o dinheiro que recebemos como pagamento, seja um bem supremo. Superior a tudo, até mesmo ao nosso tempo de vida.

Essa crença interessa ao funcionamento da sociedade capitalista que a usa para, em nome desse mega-símbolo, mover a máquina de produção e consumo, e toda a insanidade que dela advém.

Nisso estamos completamente imersos, tão imersos que até mesmo questionar esse sistema de valores parece absurdo ou ingênuo.

Alguns consideram essas questões superadas, mas sobre isso verificamos que, se elas parecem estar superadas no território do debate científico (o que também não se pode afirmar ser de todo certo...), elas certamente não estão superadas no que poderíamos chamar de ethos mediático, já que esses valores se refletem explicitamente no universo dos comportamentos assumidos nas últimas décadas como paradigmáticos da sociedade mediática. Esse é o caso, por exemplo, dos programas de reality show do tipo Big Brother nos quais as pessoas competem pelo prêmio final em dinheiro, quase sempre assumindo comportamentos que evidenciam que todos os seus valores na realidade se sujeitam alegremente ao valor supremo atribuído ao dinheiro.

Nesses casos, o dinheiro legitima e autoriza todo tipo de comportamento, o que normalmente

11 A questão do valor já foi exaustivamente abordada por economistas e sociólogos, especialmente a partir da teoria marxista sobre o capital, e por isso não é nosso interesse repassá-la. 0 que nos interessa entender é como essa absolutização do valor monetário devora alguns valores que são importantes para as práticas comunicativas. 
retoma o velho estigma do "excluído" (que reedita, por sua vez, a lógica primitiva do sacrifício), numa profusão de manipulações afetivas, preconceitos, torturas psicológicas, apelações histéricas de todo tipo e toda a larga gama de falcatruas que estiver ao alcance do competidor, deixando evidente a estreita relação entre jogo e guerra (e 0 caráter sádico do narcisista), como sabemos. Para legitimar esse comportamento (que eleva os índices de audiência) a direção do programa reforça todo o tempo que se trata de um jogo, como que apelando para 0 instinto primitivo de competição/ sobrevivência dos telespectadores.

0 que prevalece, no entanto, não é a imagem da competição, e muito menos a da sobrevivência, já que 0 contexto fútil e decadente afasta da cena qualquer possibilidade trágica, mas o padrão reiterado da absoluta falta de valores outros frente ao prêmio final em dinheiro (exceto raríssimas exceções). Já há vários anos, antes do sucesso dos reality shows desse tipo, nosso homem do baú da felicidade, Silvio Santos, já apresenta em seu programa o quadro "tudo por dinheiro", cujo título é auto-explicativo e emblemático do que se tem feito na televisão nas últimas décadas.

Também programas do tipo freak show, nos quais participantes comem insetos, mergulham partes do corpo em potes fétidos ou infestados de bichos pestilentos e encaram todo tipo de situação escatológica (literalmente "no limite"), popularizaram-se na década de noventa sobre o imperativo de que os prêmios em dinheiro "valiam a pena", gerando depois uma estética própria para a qual não deixou de haver adesão de quem o fizesse por gosto (ou, mais possivelmente, para aparecer na TV).

0 que não espantava nas telenovelas ou nos filmes americanos, ou seja, a absolutização do valor do dinheiro, passa a ser um pouco mais notável quando se transfere para o universo dos reality shows nos quais, pretensamente, não estamos totalmente no reino da ficção, não ao menos para 0 telespectador comum que acredita no teor "reality" desse tipo de show que se apresenta como mais fiel à realidade do que os programas que se assumem como ficção.

Um fenômeno também digno de nota é o dos "ricos e famosos", que saíram das colunas sociais e se espalharam por toda a mídia atual, e que na realidade são famosos por serem ricos (ou candidatos a ricos), já que, na maior parte das vezes, carecem de qualquer atrativo outro que justifique sua fama. Nestes casos, quase sempre está ausente a aura de glamour que víamos nas primeiras celebridades midiáticas, nas estrelas do cinema hollywoodiano da primeira metade do século XX ou nas cantoras de rádio brasileiras. Esse glamour da primeira fase da mídia de massa servia ainda a uma espécie de sentimento de "saudades dos deuses", manifesta pela vontade de igualar-se a eles e, como afirma E. Morin, abrigava em seu 
sentido algo mais do que apenas a marca do sucesso ou do dinheiro:

\begin{abstract}
A evolução dos deuses antigos corresponde a uma evolução sociológica profunda. A individualidade humana afirma-se segundo um movimento no qual entra em jogo a aspiração de viver à imagem dos deuses, de igualá-los, se possível. Os reis foram os primeiros a situar-se na categoria dos deuses, isto é, a considerarem-se como homens totais. Progressivamente foram sendo os cidadãos, depois a plebe, depois os escravos a reivindicar essa individualidade que os homens primeiramente atribuíram aos seus duplos, aos seus deuses e aos seus reis. Ser-se reconhecido como homem é, antes de mais nada, ver reconhecido o direito de imitar os deuses (MORIN, 1980, p. 31).
\end{abstract}

Nas últimas décadas, o glamour que trazia em si o desejo de chegar mais perto dos deuses, imitando-os, saiu de cena e em seu lugar entraram as roupas de grife, caríssimas, os lugares badalados, igualmente caríssimos, por onde circulam os assessores de imagem e os reis do marketing pessoal, ou ainda os assessores de imprensa, que garantem a constante aparição dos ricos e famosos nos eventos emblemáticos da mídia do dinheiro ${ }^{12}$. E há sempre uma multidão se acotovelando na porta para entrar nesse mundo encantando dos ricos e famosos, pessoas dispostas a gestos extremos para serem incluídas nesse mundo dos "eleitos pelo mercado".
Temos, dessa forma, a absolutização do valor do dinheiro como um dos traços culturais consagrados pela mídia contemporânea. Do outro lado do espelho da mídia, de volta ao dia-a-dia e à usurpação do tempo de vida das pessoas pela lógica capitalista da produção e do consumo, temos que esse cenário, que ainda é a realidade dos países pobres (ou dos pobres que vivem nesses países), já não parece ser mais a realidade de países abastados nos quais a economia robusta permite pequenas jornadas de trabalho e devolve, nas últimas décadas, 0 homem ao seu "tempo livre".

As últimas décadas trouxeram, inclusive, um grupo de proponentes do "ócio criativo", palestrantes e escritores que ganharam milhões com a indústria das palestras para empresários entediados e com a venda de livros para quem quer se preparar para a "economia do terceiro milênio". 0 fato é que há um grande buraco no lugar da alma do homem contemporâneo. Depois de dois séculos vampirizada pela lógica protestante/capitalista do "trabalho incessante que engrandece o homem", este homem não pode suportar o tempo livre, já que ele implica em estar consigo mesmo e dar-se conta, mais ou

Espanta-nos o fato de que os recentes escândalos (2005-2006) que envolveram o governo brasileiro acerca da CPI do "Mensalão" e da lavagem de dinheiro realizada pelo publicitário Duda Mendonça em nenhum momento mereceu das vozes que ocupam o espaço da mídia, nem mesmo nos telejornais, nem um breve comentário sobre o teor das milionárias somas em dinheiro que se dedica às verbas publicitárias para o marketing político e eleitoral no Brasil. Mais do que a corrupção política, fenômeno já bem conhecido dos brasileiros, esse sim é um fenômeno que atingiu na última década proporções alarmantes. Torna-se explícito 0 que muitos já sabíamos, ou seja, que os últimos redutos democráticos, as eleições e a manifestação da opinião pública, passaram a ser completamente definidos e matizados pelo mega-trabalho dos profissionais de marketing, que se dizem profissionais da comunicação (sic!). 
menos conscientemente, de que onde deveria haver uma alma há agora um enorme nada.

Esse vazio terá de ser preenchido por alguma coisa e as novas tecnologias da comunicação, com sua operacionalização burocrática e com os simulacros que criam são certamente o preenchimento ideal, já que de um lado oferecem um modus operandi cada vez mais complicado que demanda tempo de aprendizagem e operacionalização cada vez maior (sendo até agora uma deslavada mentira que tudo está se simplificando e que elas economizam nosso tempo), e por outro lado oferecem substitutos fáceis para os sonhos que desaprendemos a sonhar.

Esses "sonhos delivery" são a matéria-prima da mídia de massa (sim, ela ainda sobrevive!) que se desenvolve para preencher esse espaço deixado como tempo livre e apropriar-se dele de forma a aquecer mais ainda a economia de consumo, sob o pretexto da indústria do entretenimento, sobre a qual não se pode falar sério porque, enfim, seu objetivo é apenas divertir e "matar o tempo"13. Será preciso ainda um longo percurso para que se resgate no entretenimento um centro de significado mais forte do que esse do consumo, impresso por sua força geradora, o capitalismo.

Porém, as imagens sonhadas por essa indústria do entretenimento penetram o imaginário cultural, 0 inconsciente coletivo, de tal forma que hoje sonhamos os sonhos que a máquina sonhou para nós. Por isso D. Kamper disse, numa metáfora emblemática, que deus sonha o homem, 0 homem sonha a máquina e a máquina sonha deus (KAMPER, 1997).

\section{Referências}

BAUMAN, Zygmunt. Comunidade: a busca por segurança no mundo atual. Rio de Janeiro: Jorge Zahar, 2003.

BELTING, Hans. Il culto delle immagini. Roma: Carocci Editore, 2001.

BERMAN, Morris. El desencantamiento del mundo. Santiago de Chile: Cuatro Vientos, 2005.

CAMPBELL, Joseph. Isto és tu: redimensionando a metáfora religiosa. São Paulo: Landy, 2002.

(2000) A Ilusão Vital.

CAPRA, F. A Teia da vida. São Paulo: Cultrix \& Amana-Key,1997.

Conexões Ocultas. São Paulo: Cultrix \&

Amana-Key, 2004.

COELHO, Maria Claudia. A experiência da fama. Rio de Janeiro: FGV, 1999.

CONTRERA, Malena Segura; Mídia e pânico ( $2^{\circ}$. Edição). São Paulo: Annablume, 2008.

CONTRERA, Malena Segura; ROSSI, Rosali;

REINERT, Leila. Jornalismo e realidade. São Paulo: Mackenzie, 2004.

DAMÁSIO, A. 0 mistério da consciência. S. Paulo: Cia. das Letras, 2000.

DURKHEIM, Émile. As formas elementares da vida religiosa. São Paulo: Martins Fontes, 1996. 
ELIADE, Mircea. El chamanismo y las técnicas arcaicas del éxtasis. México: Fondo de Cultura Económica, 1992.

FLUSSER, Vilém. Da religiosidade: a literatura e 0 senso de realidade. São Paulo: Escrituras, 2002.

FRANKL, Viktor E. Um sentido para a vida. São Paulo: Idéias e Letras, 2005.

HILLMAN, James. Cidade e alma. São Paulo: Studio Nobel, 1993.

JAMESON, FREDRIC. Pós-modernismo - A lógica cultural do capitalismo tardio. São Paulo: Ática, 1997.

JUNG, Carl Gustav. A vida simbólica. Petrópolis: Vozes, 2000.

et al. Hombre y sentido: Círculo Eranos III.

Barcelona: Anthropos, 2004.

KAMPER, Dietmar. 0 trabalho como vida. São Paulo: Annablume, 1997.

KLEIN, Alberto C. Imagens de culto e imagens da mídia. Porto Alegre: Sulina, 2007.

LEMOS, A. et al. MÍDIA BR. Porto Alegre: Sulina, 2004. MARCONDES FILHO, Ciro. (org.) Dicionário de Comunicação. São Paulo: Paulus, 2009.

MORIN, Edgar. As estrelas de cinema. Lisboa: Livros Horizonte, 1980.

0 paradigma perdido - a natureza humana. Lisboa: Europa-América, 1988.

Cultura de massas no século XX. Rio de Janeiro: Forense-Universitária, 1990. 2 volumes.

MORIN, Edgar. Terra-Pátria. Porto Alegre: Sulina, 1995.

NËUMANN, ERIC. História da origem da consciência. São Paulo: Cultrix, 1990.

ROMANO, Vicente. Ordem natural e ordem cultural do tempo. Centro Interdisciplinar de Semiótica da
Cultura e da Mídia, 2006. Disponível em: <http:// www.cisc.org.br/portal/biblioteca/ordemnatural.pdf>. Acesso em: 25/03/2006

WEBER, Max. A ética protestante e o espírito do capitalismo, 2004.

Z0JA, Luigi. Nascer não basta. São Paulo: Axis Mundi, 1992.

História da arrogância. São Paulo: Axis Mundi, 2000. 


\begin{tabular}{|c|c|}
\hline $\begin{array}{l}\text { Outside the enchanted } \\
\text { garden: communication and } \\
\text { disenchantment of the world }\end{array}$ & $\begin{array}{l}\text { Al lado de fuera del jardín: } \\
\text { comunicación y desencantamiento } \\
\text { del mundo }\end{array}$ \\
\hline $\begin{array}{l}\text { Abstract } \\
\text { In this way, the text intends to rescue the common } \\
\text { direction present in the terms communication } \\
\text { and communion, analyzing the origins of these } \\
\text { two processes in search of its common root } \\
\text { and the quarrel concerning the social-cultural } \\
\text { conditions which promoted, at a determined } \\
\text { moment of our history, a disassociation between } \\
\text { these two processes, disassociation from which the } \\
\text { communication direction has transformed itself } \\
\text { radically, valorizing the imposition of a functionalist } \\
\text { vision over the communication. } \\
\text { Keywords } \\
\text { Disenchantment of the world. Media. } \\
\text { Incommunication. }\end{array}$ & $\begin{array}{l}\text { Resumen } \\
\text { El artículo plantea rescatar el sentido común } \\
\text { presente en los términos comunicación y comunión } \\
\text { analisando las orígenes de eses dos proceos en } \\
\text { búsqueda de su raiz comun y de la discusión acerca } \\
\text { de las condiciones socioculturales que crearon, en } \\
\text { determinados momentos de nuestra história, una } \\
\text { disociación entre eses dos procesos, disociación } \\
\text { a partir de la cual el sentido de comunicación } \\
\text { se ha transformado radicalmente, generando la } \\
\text { imposición de una mirada funcional y utilitarista } \\
\text { acerca de la comunicación. } \\
\text { Palabras clave } \\
\text { Desencantamiento del mundo. Medios. } \\
\text { Incomunicación. }\end{array}$ \\
\hline
\end{tabular}




\section{Expediente}

A revista E-Compós é a publicação científica em formato eletrônico da Associação Nacional dos Programas de Pós-Graduação em Comunicação (Compós). Lançada em 2004, tem como principal finalidade difundir a produção acadêmica de pesquisadores da área de Comunicação, inseridos em instituições do Brasil e do exterior.
E-COMPÓS I www.e-compos.org.br I E-ISSN 1808-2599

Revista da Associação Nacional dos Programas de Pós-Graduação em Comunicação. Brasília, v.12, n.3, set./dez. 2009

A identificação das edições, a partir de 2008 passa a ser volume anual com três números.

\section{CONSELHO EDITORIAL}

Afonso Albuquerque

Universidade Federal Fluminense, Brasil

Alberto Carlos Augusto Klein

Universidade Estadual de Londrina, Brasi

Alex Fernando Teixeira Primo

Universidade Federal do Rio Grande do Sul, Brasil

Alfredo Vizeu

Universidade Federal de Pernambuco, Brasi

Ana Carolina Damboriarena Escosteguy

Pontifícia Universidade Católica do Rio Grande do Sul, Brasil

Ana Silvia Lopes Davi Médola

Universidade Estadual Paulista, Brasil

André Luiz Martins Lemos

Universidade Federal da Bahia, Brasil

Ângela Freire Prysthon

Universidade Federal de Pernambuco, Brasil

Antônio Fausto Neto

Universidade do Vale do Rio dos Sinos, Brasil

Antonio Carlos Hohlfeldt

Pontifícia Universidade Católica do Rio Grande do Sul, Brasil

Arlindo Ribeiro Machado

Universidade de São Paulo, Brasil

César Geraldo Guimarães

Universidade Federal de Minas Gerais, Brasi

Cristiane Freitas Gutfreind

Pontifícia Universidade Católica do Rio Grande do Sul, Brasil

Denilson Lopes

Universidade Federal do Rio de Janeiro, Brasil

Eduardo Peñuela Cañizal

Universidade Paulista, Brasil

Erick Felinto de Oliveira

Universidade do Estado do Rio de Janeiro, Brasil

Francisco Menezes Martins

Universidade Tuiuti do Paraná, Brasil

Gelson Santana

Universidade Anhembi/Morumbi, Brasil

Goiamérico Felício

Universidade Federal de Goiás, Brasil

Hector Ospina

Universidad de Manizales, Colômbia

Herom Vargas

Universidade Municipal de São Caetano do Sul, Brasil

leda Tucherman

Universidade Federal do Rio de Janeiro, Brasil

Itania Maria Mota Gomes

Universidade Federal da Bahia, Brasil

Janice Caiafa

Universidade Federal do Rio de Janeiro, Brasil

Jeder Silveira Janotti Junior

Universidade Federal da Bahia, Brasil

\section{João Freire Filho}

Universidade Federal do Rio de Janeiro, Brasil

John DH Downing

University of Texas at Austin, Estados Unidos

José Luiz Aidar Prado

Pontifícia Universidade Católica de São Paulo, Brasil

José Luiz Warren Jardim Gomes Braga

Universidade do Vale do Rio dos Sinos, Brasi

Juremir Machado da Silva

Pontifícia Universidade Católica do Rio Grande do Sul, Brasil

Lorraine Leu

University of Bristol, Grã-Bretanha

Luiz Claudio Martino

Universidade de Brasília, Brasil

Maria Immacolata Vassallo de Lopes

Universidade de São Paulo, Brasil

Maria Lucia Santaella

Pontifícia Universidade Católica de São Paulo, Brasil

Mauro Pereira Porto

Tulane University, Estados Unidos

Muniz Sodre de Araujo Cabral

Universidade Federal do Rio de Janeiro, Brasil

Nilda Aparecida Jacks

Universidade Federal do Rio Grande do Sul, Brasil

Paulo Roberto Gibaldi Vaz

Universidade Federal do Rio de Janeiro, Brasil

Renato Cordeiro Gomes

Pontifícia Universidade Católica do Rio de Janeiro, Brasil

Ronaldo George Helal

Universidade do Estado do Rio de Janeiro, Brasil

Rosana de Lima Soares

Universidade de São Paulo, Brasil

Rossana Reguillo

Instituto Tecnológico y de Estudios Superiores do Occidente, México

Rousiley Celi Moreira Maia

Universidade Federal de Minas Gerais, Brasil

Samuel Paiva

Universidade Federal de São Carlos, Brasil

Sebastião Albano

Universidade Federal do Rio Grande do Norte, Brasil

Sebastião Carlos de Morais Squirra

Universidade Metodista de São Paulo, Brasil

Simone Maria Andrade Pereira de Sá

Universidade Federal Fluminense, Brasi

Suzete Venturelli

Universidade de Brasília, Brasil

Valério Cruz Brittos

Universidade do Vale do Rio dos Sinos, Brasil

Veneza Mayora Ronsini

Universidade Federal de Santa Maria, Brasil

Vera Regina Veiga França

Universidade Federal de Minas Gerais, Brasi

\section{COMISSÃO EDITORIAL}

Felipe da Costa Trotta I Universidade Federal de Pernambuco, Brasil Rose Melo Rocha I Escola Superior de Propaganda e Marketing, Brasil

\section{CONSULTORES AD HOC}

Arthur Autran Franco de Sá Neto I Universidade Federal de São Carlos

Carlos Eduardo Franciscato I Universidade Federal de Sergipe

Elisa Reinhardt Piedras I Universidade Federal do Rio Grande do Sul

Elizabeth Bastos Duarte I Universidade Federal de Santa Maria

Marcia Benetti Machado I Universidade Federal do Rio Grande do Sul

Sandra Maria Lúcia Pereira Gonçalves I Universidade Federal do Rio Grande do Sul

Suzana Kilpp I Universidade do Vale do Rio dos Sinos

Tattiana Gonçalves Teixeira I Universidade Federal de Santa Catarina

Vander Casaqui I Escola Superior de Propaganda e Marketing

Vicente Gosciola I Universidade Anhembi Morumb

Walter Teixeira Lima Junior I Fundação Cásper Líbero

REVISÃO DE TEXTO E TRADUÇÃO I Everton Cardoso

EDITORAÇÃO ELETRÔNICA I Raquel Castedo
COMPóS I www.compos.org.br

Associação Nacional dos Programas de Pós-Graduação em Comunicação

Presidente

Itania Maria Mota Gomes

Universidade Federal da Bahia, Brasil

itania@ufba.br

Vice-presidente

Julio Pinto

Pontifícia Universidade Católica de Minas Gerais, Brasil

juliopinto@pucminas.br

Secretária-Geral

Ana Carolina Escosteguy

Pontifícia Universidade Católica do Rio Grande do Sul, Brasil

carolad@pucrs.br 